\title{
TOWARDS INCLUSIVE ECONOMY - NECESSITY OR CHOICE IN THE CONTEXT OF THE MATERIAL SITUATION OF PEOPLE WITH DISABILITIES
}

\begin{abstract}
This article analyses the material situation of households of disabled people in an inclusive economy. It presents the results of the study based on statistical data from the households` budget survey conducted by Statistics Poland. The article compares the material situation of households in which disabled people live with the situation of households without disabled people, with an emphasis on the importance of economic inclusion as a condition factor of their situation's improvement. The study tested three research hypotheses: 1) achievement of higher income by households without disabled people; 2) higher levels of hypothetical incomes as just as useful by households of disabled people who run a business compared to disabled people who do not carry out such activities); 3) a higher risk of poverty by households with disabilities. The findings supported the hypotheses concerning differences in the material situation of the surveyed households.
\end{abstract}

Keywords: the material situation of households, disabled people.

\section{INTRODUCTION}

Nowadays, entrepreneurship is common in almost every area of human life and activity, "it takes various forms and dimensions and is not limited to the economy or economic area" (Maciejewski, Faron, 2014). Entrepreneurship - understood as a feature of activity, a way of responding to various challenges - takes on special significance. It is not only desirable, but even necessary for the proper functioning of all economic entities, regardless of their form of ownership, the nature of activity or size, as well as, various social groups, especially disadvantaged ones.

The inclusive economy is a new approach to understand and create economic processes. It assumes inclusion of disadvantages groups into a wide stream of economy. Its derivative

${ }^{1}$ Elżbieta Szczygieł PhD, Associate Professor, Department of Research on Sustainable Development, Institute of Law Administration and Economics, Faculty of Social Science, Pedagogical University of Krakow, 2 Podchorążych Street, 30-084 Kraków, Poland, e-mail: elzbieta.szczygiel@ gmail.com. ORCID: 0000-0002-8804-1071.

2 Teresa Piecuch DSc, PhD, Associate Professor, Faculty of Management, Rzeszow University of Technology, Al. Powstanców Warszawy 10, 35-959 Rzeszów, Poland, e-mail: tpiecuch@prz. edu.pl. ORCID: 0000-0003-2656-662X.

${ }^{3}$ Oleg Lozinsky MSc, Lviv Polytechnic National University, 12 Bandera street, 79013 Lviv, Ukraine, e-mail: lviv-forum@ukr.net. ORCID: 0000-0002-3435-5753. 
is an inclusive growth whose aim is "to contribute to the building of a new mainstream one centred on an economy for well-being; for the many, not the few" (Walby, 2018). This kind of growth "emphasizes ensuring that the economic opportunities created by a growth are available to all - particularly the poor - to the maximum possible extent" (Ali, Son, 2007). It manifests by the inclusive entrepreneurship, which is the concept of including social groups excluded from the labour market, wider - from the capitalist economy, their return and active participation in economic life, in the implementation of various undertakings not only business, although most often it concerns economic projects.

The aim of this article is to analyse if going to develop the inclusive economy is an necessary or is it a choice in the context of material situation of disabled people. Such the aim joins two spheres of the analysis: assumption of inclusive economy - and what's the matter with it - inclusive entrepreneurship, as well as, material situation of two groups of households: with disabled person(s) and without it (them). Previous research pointed, that supporting excluded groups of people in setting up their business can positively affect to increase of the income earned (See: Szczygieł, 2015; Szczygieł, Piecuch, 2018). Entering those groups on an active part of the labour market could change also their social situation and is convergent with actual social policy ${ }^{4}$.

The article presents, inter alia: the specificity of disability (quoting the definitions), the material situation of households with disabled persons in comparison to the households without them (analysing the average monthly income, expenditures and savings), and at risk of poverty rates (according to three poverty lines). Special attention is paid to the assessment of income utility by the different types of households, especially with regarding of running a business by the disabled people.

The article was developed in connection with the implementation of the project entitled "Work-based Entrepreneurship Training for People with Disabilities (WOT)" co-financed by the European Commission under the Erasmus + Program (No. 2016-1-PL01-KA202026055) and realised by the transnational partnership under the leadership of Centre for Education and Entrepreneurship Support.

\section{PROFESSIONAL SITUATION OF DISABLED PEOPLE}

\subsection{Definition of disability}

World Health Organization defines the disability as the problems with human functioning which are categorized in three interconnected areas: 1) impairments (problems in body function or alterations in body structure - for example, paralysis or blindness); 2) activity limitations (difficulties in executing activities - for example, walking or eating); 3) restrictions in participation (problems with involvement in any area of life ex. facing discrimination in employment). Disability refers to difficulties encountered in any or all three areas of functioning (World report on disability, 2011). Disability in that context could be understand as any limitation or inability (due to disability) to live an active life in a manner or range considered to be typical for a human being.

\footnotetext{
${ }^{4}$ I.a. EUROPE 2020, A European strategy for smart, sustainable and inclusive growth, EUROPEAN COMMISSION, Brussels 2010; Project Europe 2030 - challenges and opportunities. A report to the European Council by the Reflection Group on the Future of the EU 2030, European Union, Stuttgart 2010; Poland 2030, The Third wave of modernity. Long-term National Development Strategy, Ministry of Administration and Digitization, Warsaw 2013.
} 
In Polish legislation, disability is specified as permanent or temporary inability to fulfil social roles due to permanent or long-term impairment of the body's fitness, in particular causing inability to work (Act of 27th August 1997 On vocational and social rehabilitation and employment of disabled persons). Disability is a non-homogeneous phenomenon, not only because of the forms, but also the effects. In this regard, the law indicates three levels of disability: considerable, moderate and light. The first one concerns the situation where the fitness of the organism of a person is impaired. This person is incapable of work or only able to work in protected work conditions and requiring, in order to perform social roles, permanent or long-term care and help of other people in connection with inability to live independently. In the second case - moderate level of disability - the person with impaired fitness of his/her body requires temporary or partial help of other people in order to fulfil social roles. In the last case - light level of disability - the impaired fitness of body causes significantly reduction of the ability to perform work (compared to a person with full physical or mental fitness), but this situation can be compensated by the use of orthopaedic, ancillary or technical equipment (Act of 27th August 1997 On vocational and social rehabilitation and employment of disabled persons, art. 3 and art. 4.1-4.3.).

\subsection{Data sources of material situation of disabled people and research assumptions}

Statistics Poland is the most important source of data related with material situation of disabled people. In Household Budget Surveys, published every year there are presented the data that concern inter alia: average monthly receipts per capita in households with or without disabled persons, as well as, the average monthly outgoings per capita in the same layout. It allows to compare not only the income and the expenses, but also savings. In that source are presented the data of subjective evaluation of material situation of households in that two types of households. It allows to compare only the percentage of households assess their situation according to a five-grade category: very good, rather good, average, rather bad and bad. Another, available data, come indirectly from household budget surveys, relate the risk of poverty in that households. They are presented in other, separate publications (Range of economic poverty in Poland, Statistics Poland, Warsaw [every year]). From point of view of assessing the real income utility it is not possible to do it based on that data. Those data are collected but not published (non identified, paid data). In the present paper we used the data from the official publications concern period from 2010 to 2017 (material situation of that households and risk of poverty) and 2010-2012 (income utility) ${ }^{5}$, but also we cited the results of analysis based on the second ones (non-identified data - unit data that do not allow household identification). Years of using data are related with their availability. In case of material situation the data are open, but in case of income utility, the authors used unpublished data came from Statistics Poland and the result of analysis conducting under the project entitled "Study of utility of income in Polish households and its impact on the households".

The aim of the empirical study presented in the article was to get answers to the questions about the differences between material situation of two groups of household: with disabled person(s) and without it (them).

\footnotetext{
5 The choice of time was justified by the framework of the implementation of the project entitled: "Study of utility of income in Polish households and its impact on the households" financed with the Centre for Education and Entrepreneurship Support's own resources.
} 
The implementation of the goal formulated in this way conditioned the adoption of the following research hypotheses:

$H_{1}$ : households without disabled persons achieve higher level of income than households with them and they are more likely to postpone the consumption;

$\mathrm{H}_{2}$ : households with disabled persons conducted their own business indicate higher income levels as just as useful, than disabled people who do not carry out such activities, which means increasing the so-called inflationary lifestyle;

$\mathrm{H}_{3}$ : households with disabled persons are more at risk of poverty.

Verification of hypotheses, formulated in this way, was based on data from household budget surveys from mentioned years, including non identified data.

\subsection{Professional situation of disabled people}

The material situation is related with professional situation of people, it is particularly evident in the case of people with disabilities, who acquire this status precisely on the basis of an assessment of their ability to work and live independently. In Poland the average coefficient of professional activity of people with disabilities (PWDs) is more than two times low than the same coefficient in the group of people who are fully functional (PFFs) (Table 1). A slightly different situation concern unemployment rate. It is higher in PWDs group (minimum 1,5 times), but the in-depth analysis indicates that PWDs are more often professionally inactive.

Table 1. The professional activity coefficients and unemployment rates among PWDs and PFFs

\begin{tabular}{|c|c|c|c|c|c|c|c|c|}
\hline & \multicolumn{3}{|c|}{ The coefficient of professional activity } & \multicolumn{4}{c|}{ Unemployment rate } \\
\cline { 2 - 9 } & PWDs & PFFs & $\begin{array}{c}\text { difference } \\
\text { (PFFs-PWDs) }\end{array}$ & $\begin{array}{c}\text { relation } \\
\text { (PFFs/PWDs) }\end{array}$ & PWDs & PFFs & $\begin{array}{c}\text { difference } \\
\text { (PWDs-PFFs) }\end{array}$ & $\begin{array}{c}\text { relation } \\
\text { (PWDs/PFFs) }\end{array}$ \\
\hline 2010 & 25,7 & 71,6 & 45,9 & 2,8 & 15,3 & 9,8 & 5,5 & 1,6 \\
\hline 2011 & 26,3 & 72,1 & 45,8 & 2,7 & 15,5 & 9,8 & 5,7 & 1,6 \\
\hline 2012 & 27,5 & 72,9 & 45,4 & 2,7 & 16,2 & 10,3 & 5,9 & 1,6 \\
\hline 2013 & 27,3 & 73,5 & 46,2 & 2,7 & 17,9 & 10,5 & 7,4 & 1,7 \\
\hline 2014 & 27,1 & 74,3 & 47,2 & 2,7 & 16,1 & 9,2 & 6,9 & 1,8 \\
\hline 2015 & 25,9 & 74,1 & 48,2 & 2,9 & 13,0 & 9,3 & 3,7 & 1,4 \\
\hline 2016 & 26,8 & 75,2 & 48,4 & 2,8 & 11,6 & 6,3 & 5,3 & 1,8 \\
\hline 2017 & 28,9 & 75,9 & 47,0 & 2,6 & 9,3 & 5,0 & 4,3 & 1,9 \\
\hline
\end{tabular}

Source: own elaboration on the base of Statistics Poland, quarterly data from the Labour Force Survey (LFS).

An analysis of professional situation of disabled people should to be supported by indepth analysis of employment status (in the sense of being employed or employers) (Chart 1). In the group of employed PWDs (over than 440 thous. people in 2017), the vast majority of them were hired by the others $(86,4 \%$ in 2017). The self-employment and being employers were not as much popular as being employees. The decision of running their own business took only 11,3\% of PWDs (in 2017) and in this case the significant decrease is observed (from 21,3\% in 2010). This situation concerns also being an owner and hiring others by PWDs. For that way of earning decided only 1,6\% of PWDs in $2017(2,5 \%$ in 2010). 


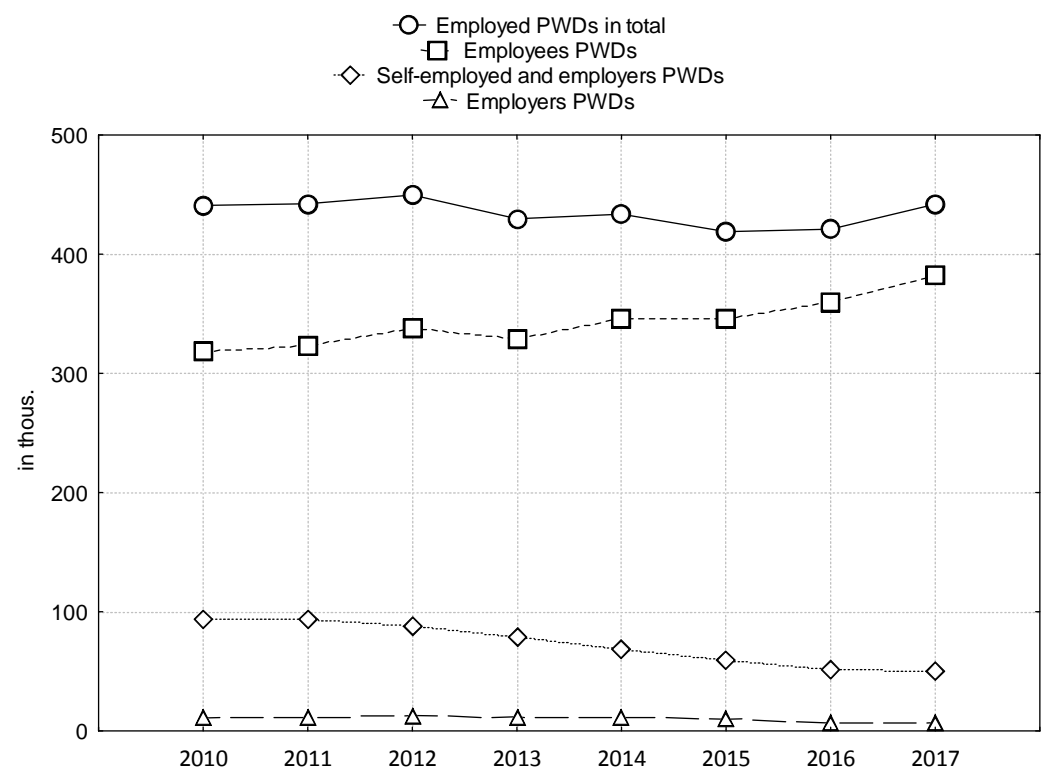

Chart 1. The employment status of PWDs in Poland

Source: as in Table 1.

The number of PWDs conducting their own business (entrepreneurs) is also possible to calculate on the base of data come from the State Fund for Rehabilitation of Disabled People (Państwowy Fundusz Rehabilitacji Osób Niepełnosprawnych - PFRON). Based on the Subsidy and Refund Management System about the number of disabled people running a business who apply for the refund of social security contributions, it can be said that the number of PWDs who are entrepreneurs is decreasing. Averaging annually the data, the number of PWDs entrepreneurs decreased by almost 5,100 persons (between 2010 and 2018) (Table 2 \& Chart 2).

Table 2. The number of PWDs entrepreneurs due to the level of disability

\begin{tabular}{|c|c|c|c|c|}
\hline \multirow{2}{*}{} & \multicolumn{4}{|c|}{ PWDs Entrepreneurs } \\
\cline { 2 - 5 } & considerable & moderate & light & in total \\
\hline 2010 & 1415,1 & 8943,2 & 17657,8 & 28016,0 \\
\hline 2011 & 1667,7 & 9835,3 & 15869,8 & 27372,7 \\
\hline 2012 & 1855,5 & 10225,3 & 12228,4 & 24309,3 \\
\hline 2013 & 1932,4 & 10750,9 & 10929,3 & 23612,7 \\
\hline 2014 & 2011,6 & 11625,8 & 10307,9 & 23945,3 \\
\hline 2015 & 2039,6 & 12185,9 & 9552,7 & 23778,2 \\
\hline 2016 & 2038,5 & 12759,8 & 9284,3 & 24082,6 \\
\hline 2017 & 2056,2 & 12959,3 & 8945,3 & 23960,8 \\
\hline $2018^{*}$ & 2013,9 & 12707,1 & 8199,0 & 22920,0 \\
\hline
\end{tabular}

Note: [2018*] - average number from eleven months (I-XI)

Source: own elaboration on the base of Subsidy and Refund Management System (SODiR) PFRON 


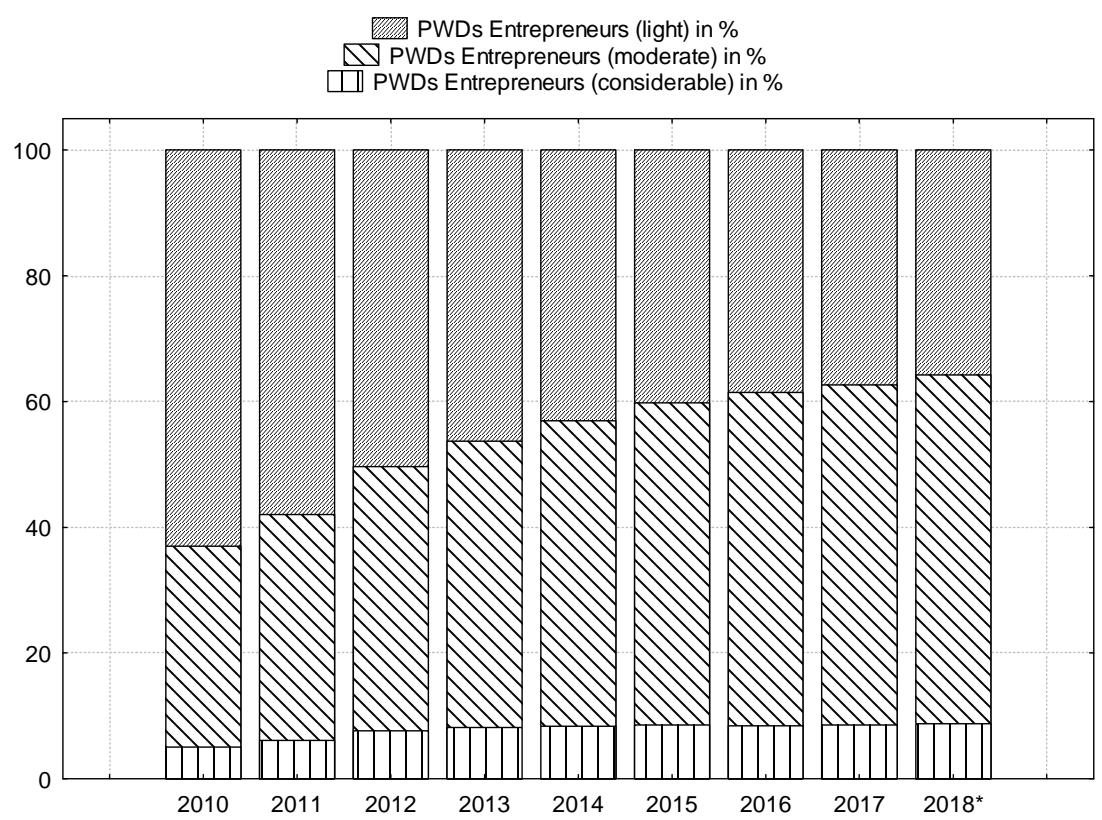

Chart 2. The percentage of PWDs entrepreneurs due to the level of disability

Source: as in Table 2.

According to those data, it can be said that the decreasing of number PWDs who are entrepreneurs is not coherent phenomenon. Although, the total number is decreasing, disabled people at considerable or moderate level become entrepreneurs more often than previously - or more precisely - they apply for the refund of social security contributions.

\section{MATERIAL SITUATION AND RISK OF POVERTY AMONG DISABLED PEOPLE}

\subsection{Monthly income, expenditures and savings as a base to assess the material} situation of disabled people

The material situation of people is presented generally by analysis of countable quantities i.a.: level of income, expenditures or savings calculated on that base (streaming approach), as well as, wealth calculated as a total fortune of household (resource approach). Due to the fact, that the total wealth is very difficult to calculate we decided to use the available data come from Statistics Poland, which are presented within streaming approach. The income taking into consideration was available monthly income of households members per capita; also the expenditures were presented as per capita values. The savings, within the meaning of this article, were the difference between average income and average expenditures. We also decided to present the assessment of income utility level, based on the non-observed statistics preparing within household budget survey, because those data show how the households members evaluate the value of similar income level. 


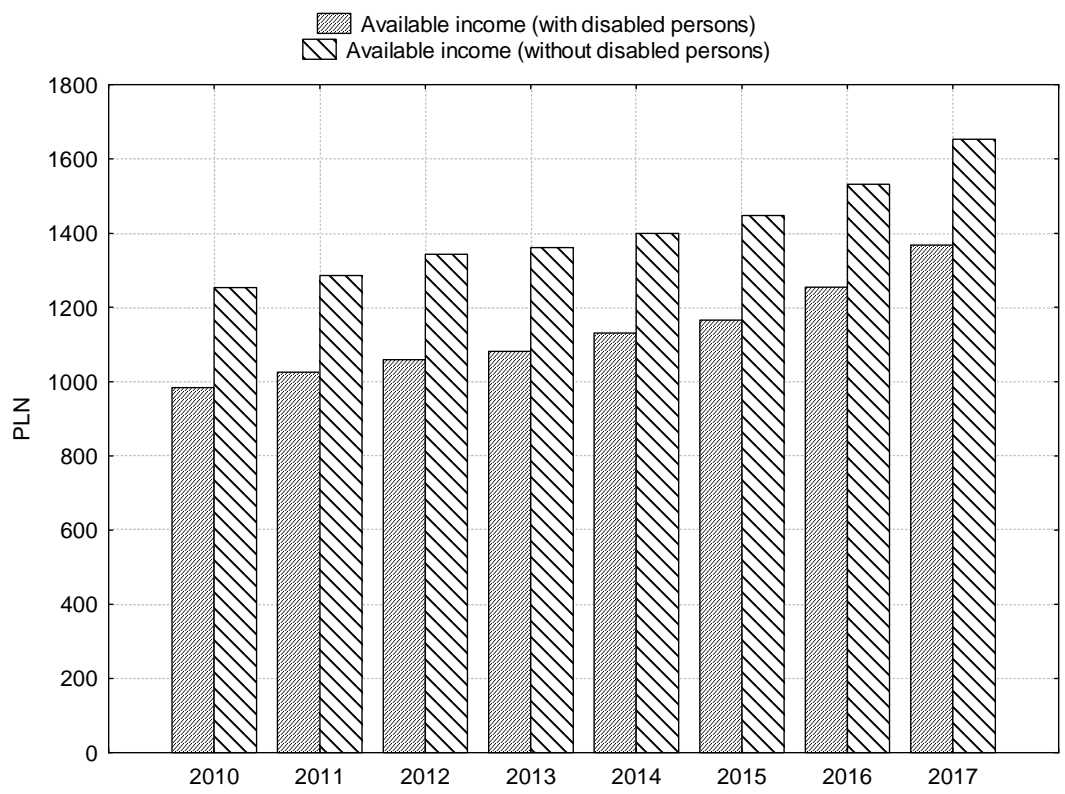

Chart 3. The amount of average available income per capita in households with or without PWDs

Source: own elaboration on the base of Range of economic poverty in Poland - Annexes, Statistics Poland.

Between 2010 and 2017 the amount of average available income per capita in households with disabled people was lower than in households without PWDs. The average difference was approx. 270 PLN in analysed time (Chart 3). What is worth o underline, the speed of growth was higher in the households with PWDs (115,3\% to 112,4\% for households without PWDs). However the nominal level of income was lower in the households with PWDs. It could be caused by the problem of ability to work among the members of that households. Analysis of source of income (income from wage labour, self-employment, an individual farm in agriculture or social insurance benefits, and etc.) showed that in households with PWDs the average level of income which came from wage labour and self-employment was almost two or three times higher in the households without PWDs. On the other hand - the income came from social insurance benefits was approx. two times higher per capita in the households with PWDs.

The average level of expenditures was also higher in the households without PWDs than those in which the disabled people lived. The average difference between those households' expenditures was almost 200 PLN, so the difference was not a mirror reflection to the income, but lower (Chart 4). The expenditures in both types of households increased, but the speed of growth was higher in the households with PWDs (109,7\% to $107,9 \%$ in households without PWDs). 


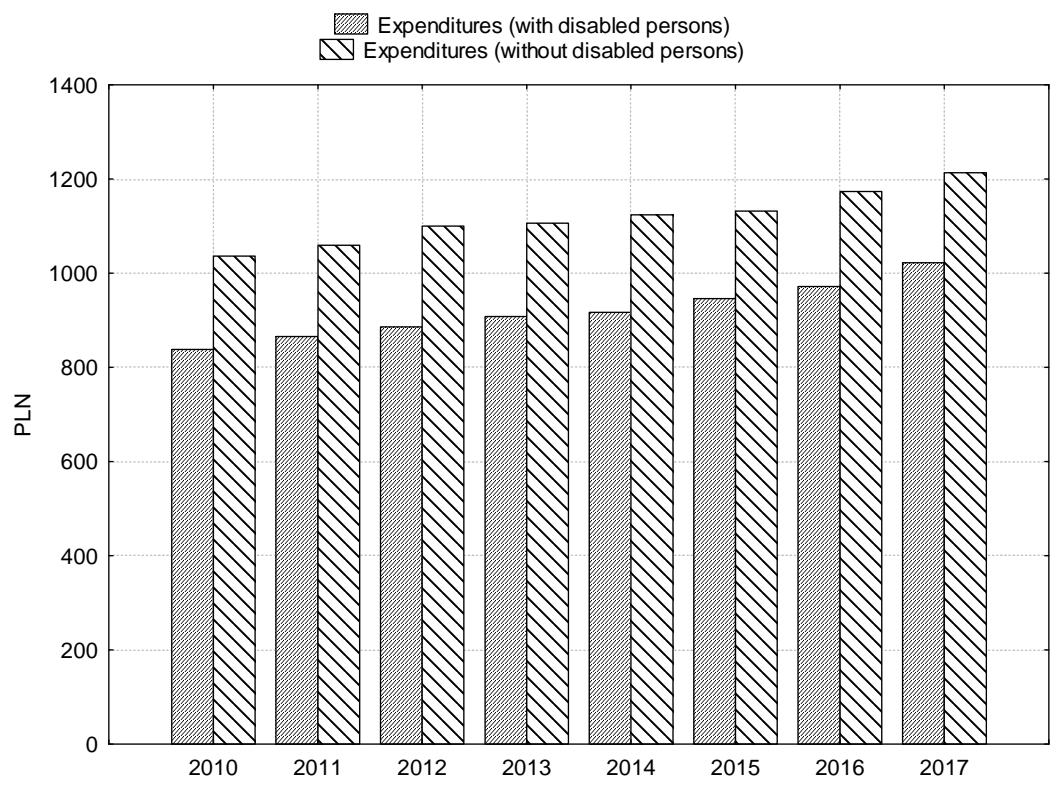

Chart 4. The amount of average expenditures per capita in households with or without PWDs Source: as in Chart 3.

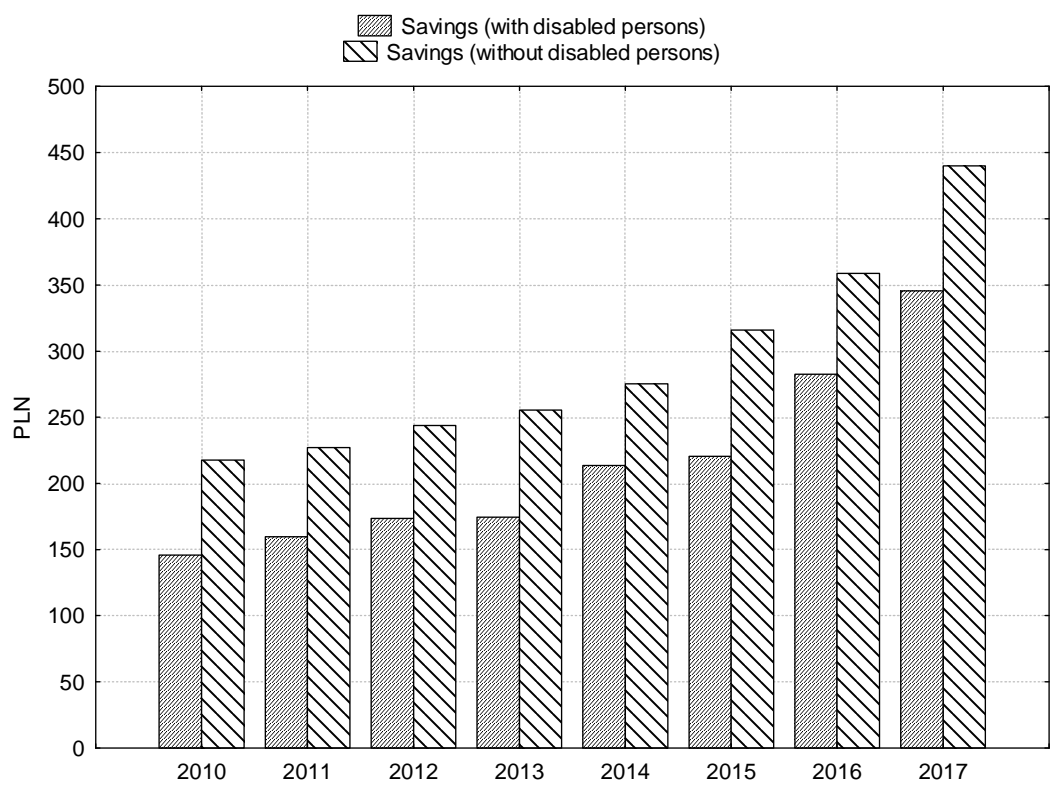

Chart 5. The amount of average savings per capita in households with or without PWDs Source: as in Chart 3. 
The households without PWDs generated the higher average level of savings than the households with PWDs. The average difference in the analyzed period of time was almost 80 PLN (Chart 5). The speed of growth was not steady but in 2017 significantly increased. This phenomenon applies to both types of households. In households with PWDs in 2016, the speed of growth reached the level of $193,5 \%$ (counting compared to $2010=100 \%$ ) and in $2017-236,8 \%$. In the households without PWDs the speed of growth was not so high, but also significant and it reached in $2016-164,9 \%$ and in $2017-202,3 \%$.

Available income of households with PWDs is constantly lower than in the households without such members. The difference counted as \% of total level of income (in all households) amounts approx. 20,5\% in analysed period. With reference to expenditures is lower and amounts $18,5 \%$, but the difference between average amount of savings is the higher and reaches $29,1 \%$ in analysed period of time (Table 3 ).

Table 3. The income, expenditures and savings of households with or without PWDs as \% of total income, expenditures and savings for all households type

\begin{tabular}{|l|c|c|c|c|c|c|}
\hline & \multicolumn{2}{|c|}{ Available income } & \multicolumn{2}{c|}{ Expenditures } & \multicolumn{2}{c|}{ Savings } \\
\hline & with PWDs & $\begin{array}{c}\text { without } \\
\text { PWDs }\end{array}$ & with PWDs & $\begin{array}{c}\text { without } \\
\text { PWDs }\end{array}$ & with PWDs & $\begin{array}{c}\text { without } \\
\text { PWDs }\end{array}$ \\
\hline 2010 & 82,5 & 105,1 & 84,5 & 104,5 & 72,5 & 108,0 \\
\hline 2011 & 83,6 & 104,9 & 85,3 & 104,4 & 75,4 & 107,3 \\
\hline 2012 & 82,9 & 105,1 & 84,3 & 104,6 & 76,2 & 107,0 \\
\hline 2013 & 83,3 & 104,8 & 85,5 & 104,2 & 73,5 & 107,6 \\
\hline 2014 & 84,4 & 104,4 & 85,0 & 104,2 & 81,6 & 105,2 \\
\hline 2015 & 84,1 & 104,4 & 86,7 & 103,7 & 74,8 & 107,1 \\
\hline 2016 & 85,0 & 103,9 & 85,9 & 103,7 & 82,3 & 104,6 \\
\hline 2017 & 85,6 & 103,5 & 86,9 & 103,2 & 82,0 & 104,4 \\
\hline
\end{tabular}

Source: as in Chart 3 - own elaboration.

Those differences can suggest that the $H_{l}$ is true, but the final confirmation of it needs to apply statistical tests. In this purpose we used the nonparametric U Mann-Whitney test for independent samples (groups) with $\alpha=0,05$. Comparing the mean level of income in both types of households, the difference between them turned out to be statistically significant $(p=0,000793 ; p<\alpha)$. The mean for the households with PWDs is 1133,67 PLN and for households without them - 1409,75 PLN. On that base, there is no reason to reject a first part of the hypothesis $H_{l}$. It means that households without disabled persons achieve higher level of income than households with them. Simultaneously, also the second part of that hypothesis should be approved, because the differences between savings in that households are also statistically significant, so it means that the households without PWDs are more likely to postpone the consumption $(p=0,000793 ; p<\alpha)$.

\subsection{Self-assessment of the material situation as a entrance to analysis of income utility}

Those differences also influences at households' self-assessment of their material situation. Based on the Statistics Poland data, concerns the self-assessment of material situation (five-step scale), the weighted average was counted (Chart 6). Only in the first year of analysis, the situation was higher assessed by the households with PWDs. The next editions 
of assessment revealed that the households without PWDs are much satisfied from their material situation than those where live PWDs. On the situation in the first year of analysis influenced the higher percentage of "rather good" assessment which was declared by $25,8 \%$ of respondents (in next years, this level was chosen by no more than $15 \%$ ).

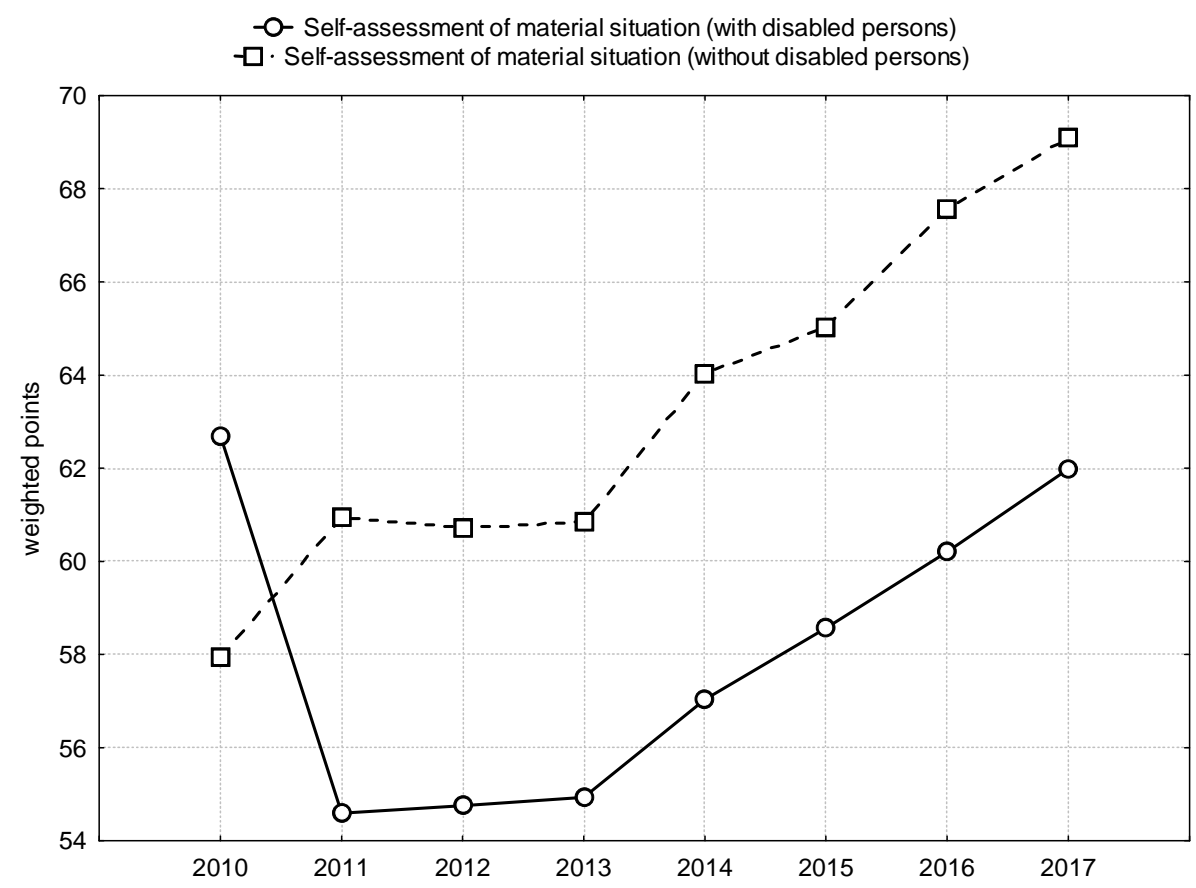

Chart 6. Self-assessment of material situation in households with or without PWDs

Source: as in Chart 3 - own elaboration.

The self-assessment of material situation is closely related with utility of income (See: Szczygieł, 2014). Based on previous analysis conducted by E. Szczygieł (elaborated with using of non identified data from households` budget survey came from Statistics Poland), it is possible to identify the significant differences between those types of households (http://problemyspoleczne.edu.pl/index.php/pl/8-aktualnosci/100-roznice-w-dochodach-iocenie-ich-uzytecznosci-w-gospodarstwach-domowych-osob-niepelnosprawnych-i-bezniepelnosprawnosci) (Chart 7). 


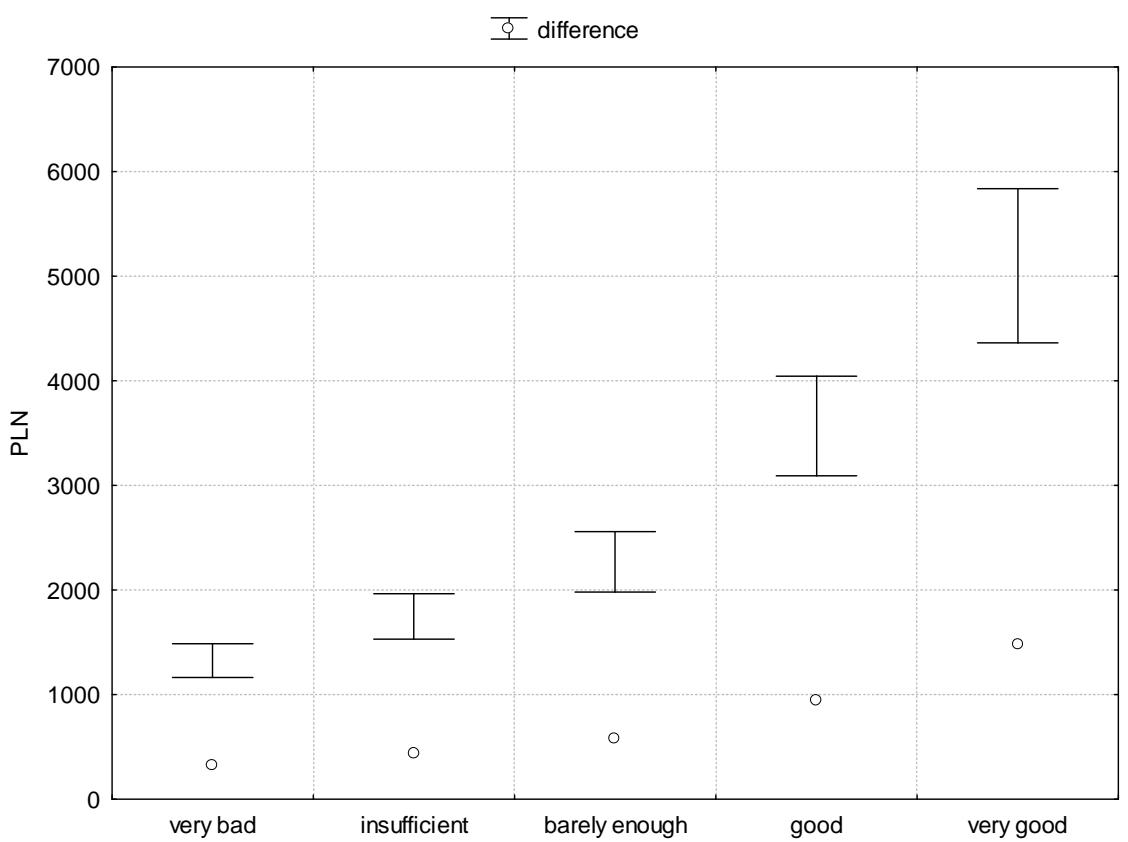

Chart 7. Differences between assessed income utility level in households with or without PWDs (in 2012)

Source: own elaboration on the base of non identified data from households` budget survey Statistics Poland.

The difference between the hypothetical level of income assessed as very bad is the lowest and increases with the transition to the next verbal assess: insufficient, barely enough, etc. The difference is marked as a dot on the chart 7 . The range values presented on the Whiskers diagram mean the hypothetical value of each income: the lower presents assessment conducted by households with PWDs; the higher - without PWDs. This regularity is also confirmed by the analysis for previous years. Also, the comparison of the real income and hypothetical assessment of its utility between PWDs and non-PWDs households conducted their own business approves the differences. Chart 8 presents the mean difference of hypothetical income assessment between disabled head of households' who conduct their own business and those who do not conduct.

Similarly, as in chart 7 on chart 8 the range values is presented on the Whiskers diagram: the higher range of difference means the hypothetical value of each income assessed by self-employed PWDs; the lower - by the other PWDs. The difference is marks as the points for each year. The biggest differences were noted on 2011. This year was also significant in terms of real income: self-employed heads of non-PWD households gained the lower real income than self-employed PWDs. Additionally, it needs to be highlighted that the real income gained by the households is higher among self-employed (both PWDs in non-PWDs) in the comparison to those households which head does not conduct their own business. It means, that income from self-employment has positively affects on the higher level of material situation. 


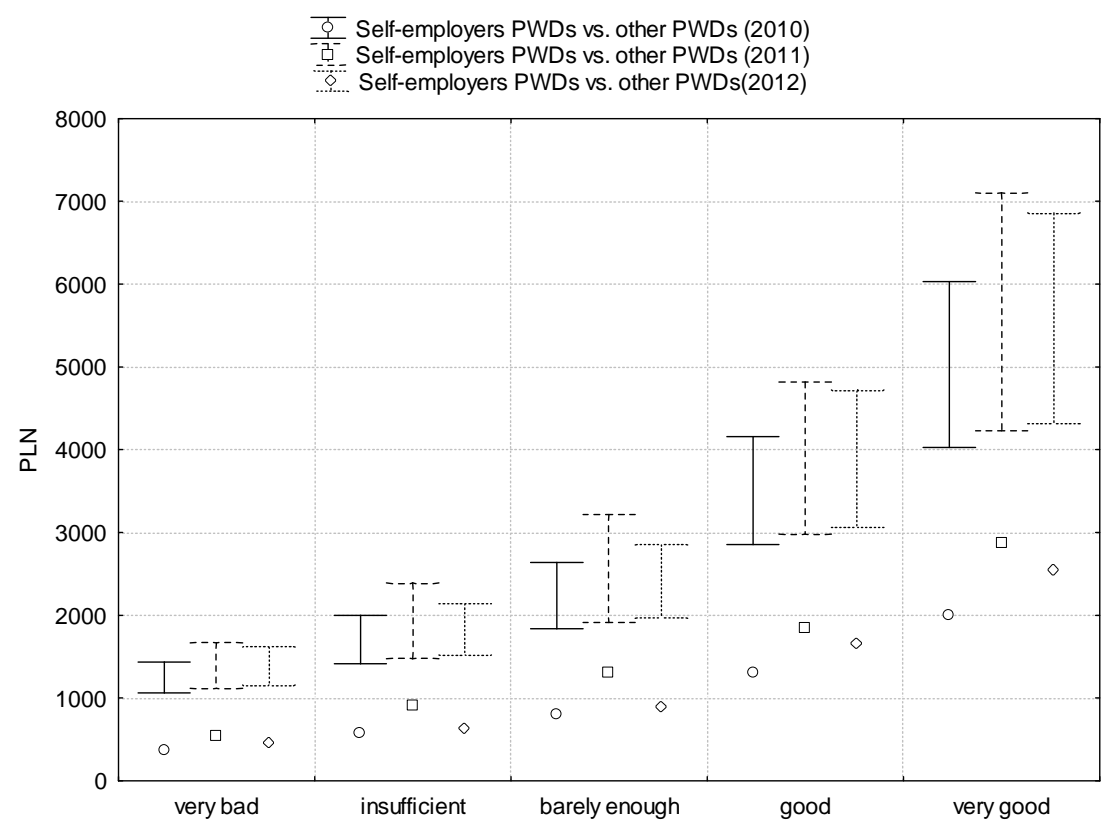

Chart 8. Differences between assessed income utility level in households of self-employed PWDs and other types of PWDs households

Source: as in Chart 7 - own elaboration.

Table 4. The results of U Mann-Whitney test for differences between assessment of income utility in both types of households

\begin{tabular}{|c|l|c|c|c|}
\hline & & $Z$ & Zdjusted Z & $p$ \\
\hline \multirow{3}{*}{2010} & Very bad & $\mathbf{2 , 1 1 2 5 0 3}$ & $\mathbf{2 , 1 3 5 7 6 1}$ & $\mathbf{0 , 0 3 4 6 4 4}$ \\
\cline { 2 - 5 } & Insufficient & $\mathbf{2 , 5 5 0 3 9 2}$ & $\mathbf{2 , 5 6 3 1 3 4}$ & $\mathbf{0 , 0 1 0 7 6 1}$ \\
\cline { 2 - 5 } & Barely enough & $\mathbf{2 , 5 8 2 7 4 4}$ & $\mathbf{2 , 5 9 4 1 4 4}$ & $\mathbf{0 , 0 0 9 8 0 2}$ \\
\cline { 2 - 5 } & Good & $\mathbf{3 , 4 4 9 2 5 6}$ & $\mathbf{3 , 4 7 1 1 7 3}$ & $\mathbf{0 , 0 0 0 5 6 2}$ \\
\cline { 2 - 5 } & Very good & $\mathbf{4 , 0 7 1 4 3 3}$ & $\mathbf{4 , 0 9 7 0 3 5}$ & $\mathbf{0 , 0 0 0 0 4 7}$ \\
\hline \multirow{8}{*}{2011} & Very bad & $\mathbf{5 , 5 5 4 5 6 5}$ & $\mathbf{5 , 6 1 1 1 0 0}$ & $\mathbf{0 , 0 0 0 0 0 0}$ \\
\cline { 2 - 5 } & Insufficient & $\mathbf{7 , 1 2 5 6 5 4}$ & $\mathbf{7 , 1 5 9 6 2 6}$ & $\mathbf{0 , 0 0 0 0 0 0}$ \\
\cline { 2 - 5 } & Barely enough & $\mathbf{7 , 4 5 4 4 4 1}$ & $\mathbf{7 , 4 8 4 6 1 9}$ & $\mathbf{0 , 0 0 0 0 0 0}$ \\
\cline { 2 - 5 } & Good & $\mathbf{7 , 7 5 2 9 0 4}$ & $\mathbf{7 , 7 9 8 0 9 9}$ & $\mathbf{0 , 0 0 0 0 0 0}$ \\
\cline { 2 - 5 } & Very good & $\mathbf{7 , 7 7 5 6 1 0}$ & $\mathbf{7 , 8 1 8 1 6 9}$ & $\mathbf{0 , 0 0 0 0 0 0}$ \\
\hline \multirow{3}{*}{2012} & Very bad & $\mathbf{5 , 6 9 6 6 5 0}$ & $\mathbf{5 , 7 4 8 3 5 3}$ & $\mathbf{0 , 0 0 0 0 0 0}$ \\
\cline { 2 - 5 } & Insufficient & $\mathbf{7 , 0 2 8 8 2 8}$ & $\mathbf{7 , 0 6 0 1 3 8}$ & $\mathbf{0 , 0 0 0 0 0 0}$ \\
\cline { 2 - 5 } & Barely enough & $\mathbf{7 , 6 6 6 6 4 5}$ & $\mathbf{7 , 6 9 7 1 5 0}$ & $\mathbf{0 , 0 0 0 0 0 0}$ \\
\cline { 2 - 5 } & Good & $\mathbf{8 , 5 6 2 4 1 3}$ & $\mathbf{8 , 6 1 0 0 3 0}$ & $\mathbf{0 , 0 0 0 0 0 0}$ \\
\cline { 2 - 5 } & Very good & $\mathbf{8 , 5 2 4 8 3 8}$ & $\mathbf{8 , 5 7 3 4 0 1}$ & $\mathbf{0 , 0 0 0 0 0 0}$ \\
\hline
\end{tabular}

On bold - statistically significant differences. Source: own elaboration. 
The results of the above analysis was also confirmed by using statistical test. After a comparing the hypothetical level of each income assessment by using U Mann-Whitney test, there is no reason to reject the hypothesis $H_{2}$ (table 4). It means that the households with disabled persons conducted their own business indicate higher income levels as just as useful, than disabled people who do not carry out such activities. In effect it means increasing the so-called "inflationary lifestyle" (See: Szczygieł, Piecuch, 2018).

\subsection{Risk of poverty among people with disabilities}

Risk of poverty used to be considered with using of poverty lines below them the poverty phenomenon appears. In the present paper, we used three, most popular poverty lines: the subsistence minimum, the relative poverty line and the statutory poverty line (See: Range of economic poverty in Poland in 2017, 2018 - Annex.) Those lines are used by Statistics Poland in their analysis related with this topic. The range values presented on the Whiskers diagram mean the level of being at risk of poverty in both types of households: the lower in households with PWDs; the higher - without PWDs (Chart 9).

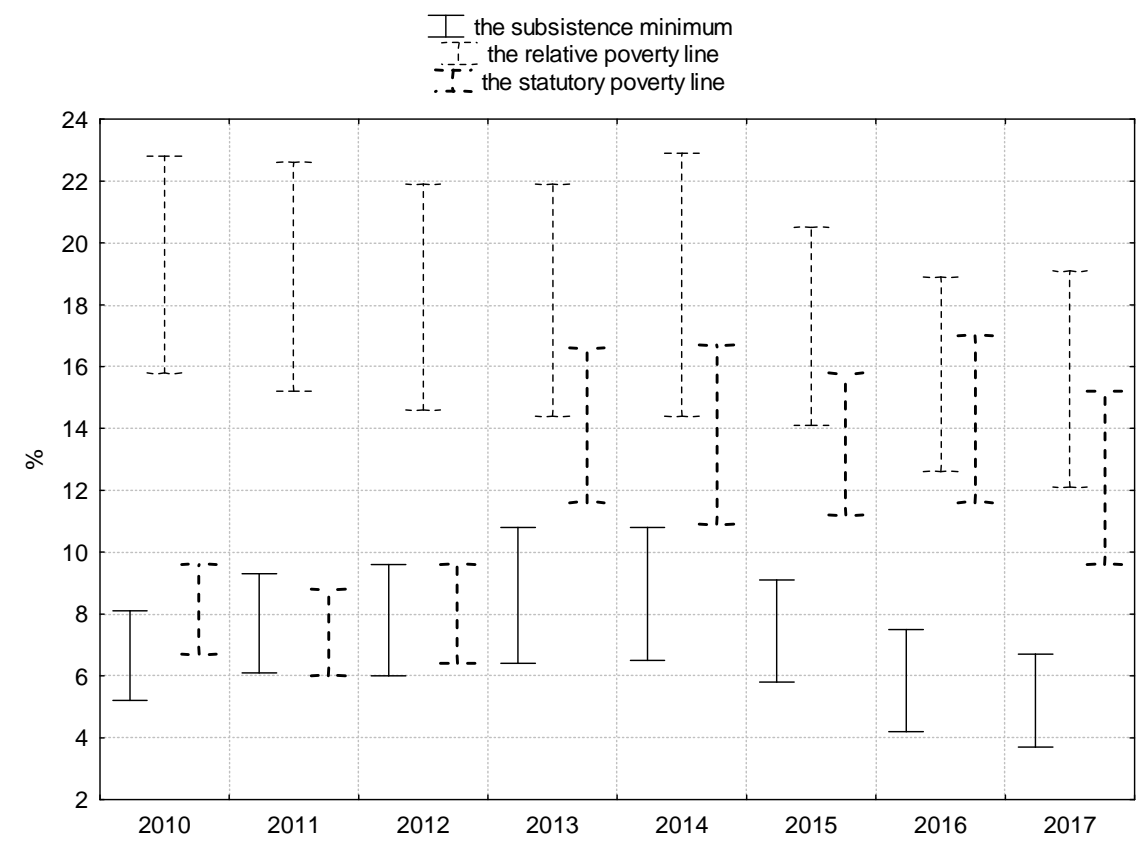

Chart 9. Differences between households with min. 1 PWD person and without PWDs in three values of poverty lines in analysed period (2010-2017)

Source: as in Chart 3

The range of differences between the subsistence minimum in households with and without PWDs consisted on average 3,5\% in the period of analysis. Of course the highest level of risk of poverty was noted in households with PWDs. In the case of the relative poverty line it was $7,2 \%$ and in case of the statutory poverty line $-4,4 \%$. 


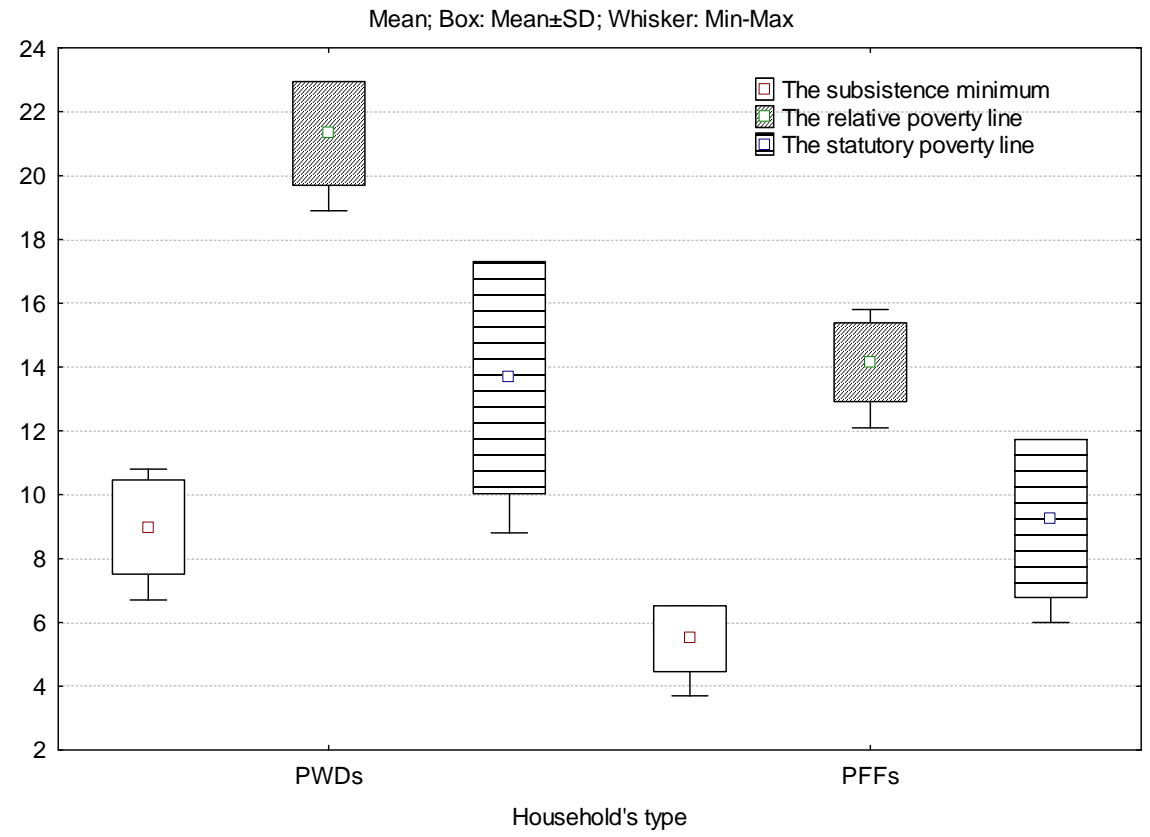

Chart 10. Differences between households with min. 1 PWD person and without PWDs in three values of poverty lines (summary)

Source: as in Chart 3.

In order to confirm statistically significant differences between all three poverty lines for PWDs and non-PWDs households, we decide to use also U Mann-Whitney test (Table 5).

Table 5. The results of U Mann-Whitney test for differences between three poverty lines assessment in both types of households

\begin{tabular}{|l|c|c|c|}
\hline \multicolumn{1}{|c|}{ Poverty line } & $\mathrm{Z}$ & Adjusted Z & $P$ \\
\hline The subsistence minimum & $\mathbf{3 , 3 6 0 6 7 2}$ & $\mathbf{3 , 3 6 3 1 4 6}$ & $\mathbf{0 , 0 0 0 7 7 8}$ \\
\hline The relative poverty line & $\mathbf{3 , 3 6 0 6 7 2}$ & $\mathbf{3 , 3 6 5 6 2 5}$ & $\mathbf{0 , 0 0 0 7 7 8}$ \\
\hline The statutory poverty line & 1,890378 & 1,897367 & 0,058708 \\
\hline
\end{tabular}

On bold - statistically significant differences.

Source: own elaboration.

The statistically significant difference is observed for the subsistence minimum and the relative poverty line $(p<\alpha)$. The difference between the level of poverty risk between two analysed types of households (counted as statutory poverty line) is statistically insignificant, what caused that hypothesis $\left(H_{3}\right)$ for that poverty line should be rejected. Households with disabled persons are more at risk of poverty only when we use the subsistence minimum or relative poverty line. 


\section{INCLUSIVE ENTREPRENEURSHIP AS A PART OF INCLUSVE ECONOMY}

Inclusive entrepreneurship is a new concept in entrepreneurship ${ }^{6}$. Generally speaking, it is a concept of including social groups which are excluded from the labour market, and more broadly from the capitalist economy, their return and active participation in economic life, in the implementation of various undertakings - not only business - although most often it concerns economic projects (Wach, 2015). It creates equal opportunities for various social groups in fulfilling their aspirations and dreams, as well as, in the implementation of various types of enterprises - economic and non-economic. In other words, it contributes to equalizing opportunities for entrepreneurship, so that the possibilities resulting from it are available to all interested persons (Martinez, ed., et al., 2018). Inclusive entrepreneurship concerns, i.e.: entrepreneurial activity of women, seniors, young people, people with disabilities, immigrants, various ethnic groups (including national minorities) or unemployed people (Wach, 2015). Therefore, its beneficiaries could be "weaker population groups, which for various reasons have a worse chance of functioning in society, what often leads to social exclusion (Cieślik, 2014). These are people disadvantaged and underrepresented in terms of entrepreneurship and self-employment in some respects (including mentioned previously groups) (http://www.oecd.org/cfe/leed/inclusive-entrepreneurship.htm). Inclusive entrepreneurship offers these individuals and their families the opportunity to gain economic independence and stability, contributes to social inclusion, giving equal opportunities to do business. It can also contribute to the increase of the sense of identity and self-esteem and have a positive impact on the health of some dysfunctional persons (ex. disabled) (Martinez, ed., et al., 2018).

As mention above, inclusive entrepreneurship includes, inter alia, the entrepreneurship of people with disabilities. Their situation on the labour market is particularly difficult. Due to various types of dysfunctions, their professional activity is, for obvious reasons, at a fairly low level. The low rate of professional activity of people with disabilities may attracts a high percentage of those who decide to undertake individual business activities. Such a situation may result from many different reasons. One of the most important is probably the great determination of action and the willingness to provide for a livelihood in a situation where it is impossible to obtain any work. It is also worth pointing out different levels of disability, some (especially in the case of light) do not constitute such a big obstacle, especially to conduct certain types of activity. Large possibilities (qualitatively different) are also created by the Internet today, which in the case of people having, for example, mobility problems is a great opportunity. It also facilitates individual (flexible) regulation of working time, which is extremely important for people with disabilities, and what is difficult to achieve in the case of full-time work, even despite the friendliness and positive attitude of the employer and the facilities that are legally vested in this group of employees (Cieślik, 2014). Activation of disabled people carried out as part of inclusive entrepreneurship is a very important aspect of preventing disadvantaged people from social exclusion, with a particularly difficult situation on the labour market.

${ }^{6}$ This term was created at the University of Syracuse on the basis of a successful entrepreneurship program for disabled people and those with low incomes. The program has identified unique tools and processes that entrepreneurs must overcome. It was a four-level entrepreneurial model, with an emphasis on $1^{\text {st }}$ stage, which used self-assessment tools to help beginner entrepreneurs identify and implement their passions, define strengths and make them a business dimension (See: Martinez (ed.), Malinowska, Radoń, Ambrogi, Marcus, Szczygieł, 2018). 
Inclusion is a value in itself. It is the driving force of innovation, competitiveness and efficiency, and thus improving the quality of people's lives. An inclusive system counteracts exclusion, frees and drives creativity and entrepreneurship by strengthening positive ties based on a sense of security, trust and commonality of interest. An inclusive economy is a system based on as many as possible sovereign and equal participants, connected more by bonds of partnership and conscious interdependence than hierarchy and subordination in relations between the state - citizen - business - social groups (Mączyńska, Gospodarka inkluzywna..., https://www.bgk.pl/files/public/Pliki/news/Konferencje_BGK/XII_Konferencja_BGK...). It means, on the scale of national economies, that way of the economic growth creation, in which all of citizens participate and all of them can enjoy the benefits of it (Kot, Kraska, 2017).

There is more and more evidence that the inclusion of the socio-economic system is an indispensable condition for harmonious development, while social exclusion (i.e. excessive inequality) and the non-inclusivity of the system hamper development and cause crisis. The fundamental elements of an inclusive socio-economic system are (Mączyńska, Gospodarka inkluzywna..., https://www.bgk.pl/files/public/Pliki/news/Konferencje_BGK/XII_Konferencja_BGK...):

- institutions of social inclusion - understood as: 1) achievements of civilization, directed at the development and strengthening of these gains; 2) regulations, regarding among others the issues such as universal social security and health protection, universal access to education, guaranteed minimum wage, trade union rights, equality, common goods and other;

- inclusive enterprises - oriented towards optimal absorption of knowledge, innovation and effective reconciliation of interests in the world of work, capital and social interest;

- inclusive market - characterized by optimal, socially accepted entry and exit rules; it is perceived as a guarantor of the contract culture, symmetry of contractors' rights, including competition protection and consumer rights

- inclusive state and law as well as self-government institutions - it is a guarantee of justice and respect for the law, support for creativity, innovation, civic initiatives, development of pro-inclusive institutions and, as a system preventing the creation of exploitative institutions and preventing inequalities in access to law.

\section{CONCLUSION}

Economic inclusion, expressing itself in participation in open labour market, seems to be key factor in improvement of material situation of each households. This positive effect is observed clearly, when we analysed the situation concerns two different groups. In present paper, we conducted the analysis for households where disabled people live and compare it with the situation of households of fully functioned people. The obtain results of empirical study, presented in the article, allowed us to get answers to the questions about the differences between material situation of that two groups of household [with disabled person(s) and without it (them)]. The effect of statistical hypothesis' verification confirmed adopted assumptions. In the reference to the first hypothesis $\left(H_{l}\right.$ : households without disabled persons achieve higher level of income than households with them and they are more likely to postpone the consumption), we could say that the differences refers not only the income or the savings but also expenditures. The difference between all three categories 
(for two analysed types of households) is statistically significant. It means that households without disabled people achieve higher income, realize higher expenditures and - despite this - achieve higher level of savings. In case of the second hypothesis $\left(H_{2}\right.$ : households with disabled persons conducted their own business indicate higher income levels as just as useful, than disabled people who do not carry out such activities, which means increasing the so-called inflationary lifestyle), based on non-identified data, we showed that conducting own business is strictly related with assessing higher levels of hypothetical income. This dependence is observe not only in households of PWDs, but in other types (See: Szczygieł, Piecuch, 2016). This observation confirms the inflationary lifestyle thesis of entrepreneurs' households and allows to think about positive affect of conducting the business on economic aspiration and - in effect - on the material situation of this type of households. In reference to the third hypothesis $\left(H_{3}\right.$ : households with disabled persons are more at risk of poverty), we showed that statistically significant risk of poverty depends on the poverty line. In case of the subsistence minimum and relative poverty line, the poverty risk is higher in PWDs' households, but we cannot say that, based on statutory poverty line.

All results allow us to think that economic inclusion expressing itself by participation in open labour market, conducting own business, leads to improving material situation of each excluded household. Inclusion should be a new orientation in thinking about the economy, because it assumes better, socially justice access to benefits.

\section{REFERENCES}

Ali I., Son H.H. (2007). Defining and Measuring Inclusive Growth: Application to the Philippines. ERD Working Paper No. 98.

Cieślik J. (2014). Przedsiębiorczość, polityka, rozwój. Warszawa: Ed. SEDNO.

Dessy Martinez J.L. (ed.), Malinowska M., Radoń A., Ambrogi M., Marcus B., Szczygieł E. (2018). Jak doradzać osobom niezdolnym do pracy $w$ rozwijaniu przedsiębiorczości inkluzywnej. Przewodnik. Rzeszów: Fundacion Docete Omnes, Stowarzyszenie „Centrum Wspierania Edukacji i Przedsiębiorczości”, Granada - Rzeszów.

EUROPE 2020 (2010). A European strategy for smart, sustainable and inclusive growth, EUROPEAN COMMISSION, Brussels.

http://problemyspoleczne.edu.pl/index.php/pl/8-aktualnosci/100-roznice-w-dochodach-iocenie-ich-uzytecznosci-w-gospodarstwach-domowych-osob-niepelnosprawnych-i-bez-niepelnosprawnosci

http://www.oecd.org/cfe/leed/inclusive-entrepreneurship.htm

Kot J., Kraska E. (2017). Inkluzywna gospodarka - aspekt teoretyczny na przyktadzie województwa świętokrzyskiego. „Studia i Materiały. Miscaellanea Oeconomica”, Vol. II, No. 2.

Labour Force Survey (LFS), Statistics Poland, Warsaw (every year).

Maciejewski W., Faron A. (2014). Edukacja ekonomiczna i przedsiębiorcza a postawy przedsiębiorcze osób bezrobotnych. „Finansowe i organizacyjne aspekty kooperacji nauki i lokalnej przedsiębiorczości” (ed. Ł. Sułkowski, M. Walczak), Przedsiębiorczość i Zarządzanie, Vol. XV, Issue 10, part II, Łódź-Garwolin.

Mączyńska E., Gospodarka inkluzywna - wymiar samorzadowy. Access on the internet: https://www.bgk.pl/files/public/Pliki/news/Konferencje_BGK/XII_Konferencja_BGK_dla_ JST/Materialy_konferencyjne/Elzbieta_Maczynska_Gospodarka_inkluzywna_-_wymiar_ samorzadowy.pdf 
Poland 2030, The Third wave of modernity. Long-term National Development Strategy (2013). Ministry of Administration and Digitization, Warsaw.

Project Europe 2030 - challenges and opportunities. A report to the European Council by the Reflection Group on the Future of the EU 2030 (2010). European Union, Stuttgart.

Range of economic poverty in Poland, Statistics Poland, Warsaw (every year with Annex).

Szczygieł E. (2014). Ocena użyteczności dochodu i jej wpływ na oszczędności gospodarstw domowych. Warszawa: WNT.

(2015). Poverty and social exclusion in selected European countries. Rzeszów: CWEP.

Szczygieł E., Piecuch T. (2018), Rolnicy i przedsiębiorcy - indywidualne dziatanie i dwie drogi rozwoju. „Nierówności Społeczne a Rozwój Gospodarczy”, No. 54.

— (2016). Rozktady dochodów przedsiębiorców i ich użyteczność na tle innych grup społeczno-ekonomicznych. „Nierówności Społeczne a Rozwój Gospodarczy”, No. 48.

Wach K. (2015). Przedsiębiorczość seniorów jako komponent przedsiębiorczości inkluzywnej: wstęna synteza. „Horyzonty Wychowania”, Vol. 14, No 32.

Walby S. (2018). The concept of inclusive economic growth, „Soundings”, Spring, Issue 68.

World report on disability (2011). World Health Organization \& World Bank, Geneva.

\section{LEGAL ACTS}

Act of 27th August 1997 On vocational and social rehabilitation and employment of disabled persons [Ustawa z dnia 27 sierpnia 1997 r. o rehabilitacji zawodowej i społecznej oraz zatrudnianiu osób niepełnosprawnych], (Dz.U. z 1997 r., nr 123, poz. 776).

\section{DATABASES}

Subsidy and Refund Management System (SODiR) PFRON

DOI: $10.7862 /$ rz.2019.hss.47

The text was submitted to the editorial office: May 2019.

The text was accepted for publication: December 2019. 